\title{
The Split Session of the California Legislature
}

\section{INTRODUCTION}

In the perennial search for methods and machinery designed to make more effective and responsible the process of state legislation and to improve the legislative output, a considerable amount of favorable attention has been directed toward the split session plan in California. Certain virtues concerning it have been plausibly argued and its adoption as a remedy for legislative defects has been urged in other states. ${ }^{1}$ Latterly, however, observers of the plan in operation have come seriously to doubt its efficiency, to question whether there has been much improvement, and whether the promise has been borne out by the performance. The plan has been in effect in the state for a period of over eighteen years and may be reasonably said to have had a fair trial. It is the purpose of this paper to examine briefly the adoption of the divided session and to indicate certain salient features of its operation.

At a special election, held on October 10, 1911, the following amendment to the state constitution was adopted:

Art. IV. Sec. 2. "The sessions of the legislature shall be biennial, unless the Governor shall, in the interim, convene the legislature, by proclamation, in extraordinary session. All sessions, other than extraordinary, shall commence at twelve o'clock, $M x$., on the first Monday after the first day of January next succeeding the election of its members, and shall continue in session for a period not exceeding thirty days thereafter; wbereupon a recess of both houses inust be taken for not less than thirty days. On the reassembling of the legislature, no bill shall be introduced in either house without the consent of three-fourths of the members thereof, nor shall more than two bills be introduced by any one member after such reassembling."

The amendment had been submitted by the legislature of 1911 , together with other proposals which included the initiative, referendum, and recall, woman suffrage, and additional public utility regulation. The idea of the split session had not been mentioned in Governor Johnson's

1 Only one other state, West Virginia, has ever bad the plan. It was in effect there during the years 1921-29. Its operation was unpopular and unsatisfactory, and in 1929 the state returned to a single session of sixty days. In 1930 the constitution of Texas was so amended as to provide for a modified form of the divided session. There is no recess period; the first tbirty days are devoted primarily to the introduction of bills and resolutions, the second thirty days to committee hearings, and the final sixty days to the consideration of pending bills and resolutions. There is thus a division of legislative labor. TEx. Const. Art. V. \$3. New Jersey does not have the formal split session. It is customary, however, for the legislature to meet, organize, and then adjourn for about ten days, while the party organizations develop their plans on proposed legislation. The New Jersey practice is respectively criticized and defended by various observers. The plan has been unofficially suggested in recent years in New York, Pennsylvania, and Arkansas. 
inaugural address, nor in the several platforms of the Lincoln-Roosevelt League, an organization of progressives with a specific program of governmental and political reform. No mention was made of it either in the Republican or Democratic state platforms of 1910, althougl both docuinents, especially the former, were vigorously progressive. ${ }^{2}$ The origin of the proposal remains somewhat obscure, but considerable evidence seems to indicate that it was fostered by Anthony Caminetti, in 1911 serving his third term in the state senate. ${ }^{3} \mathrm{He}$ was a well known and influential Democrat, in complete accord with the policies of the progressives. ${ }^{4}$ His legislative experience had covered a period when corporation and machine infiuence had been pervasive and all-powerful in law making. $\mathrm{He}$ believed that three of the greatest objections were the lack of consideration and of publicity which important legislation received, and the almost incredible speed and recklessness with which bills were introduced, passed, and hurried to the statute books. Convinced that legislation and public opinion could be brought into conformity by the mechanical device of "taking the legislature to the people," he apparently originated the ingenious plan of the split session which seemed, in theory, satisfactorily to meet some of the objections so obvious in the older practices. The victory of the progressive forces in the canpaign of 1910 presented an opportunity to the veteran and popular legislator to press his claims.

Early in the subsequent session he introduced in the senate a constitutional amendment relating to the sessions of the legislature, which, after the usual procedure, was nuade a special order of business and was adopted by a large majority. ${ }^{5}$ There was apparently only perfunctory discussion of the proposal, many nembers being quite willing to support the resolution because of their friendship and affection for "Old Cam." Others believed the assenbly would not pass it, and they preferred to place the responsibility for its defeat on the other house. The leaders of the assembly, however, were inclined to regard the idea favorably. ${ }^{6} \mathrm{Cami}-$ netti personally urged his friends in the lower house, regardless of party, to support the amendment and was apparently successful in convincing

\footnotetext{
2 For these various documents see HICHBorn, Story of the CALIForNIA LegisIATURE OF 1911 (1911) Appendix, I-XVI, XIX-XXIX.

${ }^{3} \mathrm{Mr}$. Caminetti had had a long legislative career which commenced in 1882. He had served three terms in the Assembly, three in the Senate, and two in the House of Representatives. From 1913 to 1921 he was Commissioner-General of Immigration.

4 He has been characterized by a competent observer as the "Iast of the militant anti-Southern Pacific law-makers." Grant, The BicamIrrat PrINCIPLE IN THE Cazifornta Legislature, 50 (Mss. Copy).

5 Senate Journat, 39th session (1911) 103, 210, 385, 548, 588-89. The final vote was $30-9$.

${ }^{B}$ Former Governor C. C. Young to the writer, Jan. 20, 1930.
} 
some of them that the idea had substantial merit. The assembly committee on constitutional amendments, near the close of the session, reported out favorably the resolution embodying the amendment and recommended its passage. ${ }^{7}$ During the third reading of the resolution two important amendments were offered and adopted. The first reduced from 90 to 30 days the minimum interval between the first and second parts of the session; the second, sponsored by C. C. Young, declared that "nor shall more than two bills be introduced by any one member after such reassembling." 8 The advocates of the second amendment realized that if some himitation were not placed on the introduction of bills during the second part of the session, members would be inclined to hold in reserve all, or practically all, of their bills until they returned from the recess. ${ }^{9}$ This would, of course, defeat one of the most important purposes of the split session. A third and trivial change was also made when the assembly, in an excess of caution, provided that "the members of the Legislature shall be entitled to receive mileage at the rate fixed by law for their attendance on said session after said recess." The final vote in the lower house was close; the resolution carried by a vote of 56 to 22,54 affirmative votes being necessary to submit a constitutional amendment. ${ }^{10}$

Subsequently, the senate concurred in the first two amendments but rejected the third. ${ }^{11}$ The assembly thereupon voted by a large majority to recede from the third amendment and the resolution was ordered to enrollment by the senate. ${ }^{12}$ Shortly before the adjournment of the legislature Governor Johnson in a special message warmly congratulated that body upon its legislative achievements and mentioned specifically the significant items. ${ }^{13} \mathrm{He}$ did not include the amendment providing for the split session, or Amendment No. 6, as it was soon to be designated.

In the campaign for the adoption of the various constitutional amendments, the divided session proposal received only perfunctory consideration. No less than twenty-three separate propositions were submitted to the electorate in October, 1911. Interest and attention were concentrated, however, on the amendments providing for direct legislation and the recall; for woman suffrage; and for more extended state control

7 ASSEMrLI JourNat, 39th session (1911) 1905.

8 Ibid. 2164-2165. Probably the chief reason for reducing the ininimum recess period to thirty days was due to the behief that the weather conditions in Sacramento would not be propitious if the session extended into the summer. If the legislature so desired, however, it could provide for any interval deemed necessary. It has been the practice to limit the recess to a period of approximately thirty days.

$\theta$ C. C. Young to writer, Jan. 20, 1930.

10 Assearbly JourNaL, 39th session (1911) 2320.

11 Senate Journal, 39th session (1911) 2440-2411.

12 Ibid. 2508, 2649.

13 Ibid. 2674-75. 
over railroads. The avowed purposes of the divided session amendment, more care and greater publicity in legislation, were generally endorsed, but considerable doubt was expressed as to whether a bifurcated session would be effective in achieving those results. ${ }^{14}$ It was also clear that there was nothing in the amendment to prohibit the enactment of laws during the first thirty days of the session, which practice, if adopted, obviously would destroy the basic advantages of the plan. However that may be, under the vigorous leadership of Governor Hiram Johnson the more significant amendments were adopted, carrying with them the divided session proposal. ${ }^{15}$ There was apparently neither orgamized opposition to, nor support for, the amendment, and many electors no doubt voted for it without a very clear idea as to just what the results would be.

At the time of the adoption of the plan, there were already incorporated into the constitution of California important restrictions upon legislative procedure. The framers of the constitution of 1879 had apparently intended to compel the legislature to consider carefully pending legislation as well as to prohibit certain procedural practices which had developed. Thus, specific provision was made for three separate readings, for the complete printing of all bills and amendments, and for the approval by a majority of the entire membership of each house in the final passage of legislation..$^{16}$. The results were hardly encouraging. The process of legislation proceeded substantially as before. Most of the restrictions were more honored in the breach than in the observance.

In the consideration and passage of legislation subsequent to 1879 there was devastating proof that the California legislature was not much different from similar bodies in other states. An increasingly large number of bills were introduced; many were passed without adequate consideration. There was no substantial reduction in the large amount and important content of legislation hastily enacted during the end of the session rush. In view of these facts, many skeptics watched with doubtful hope the introduction of another limitation upon the legislature in the form of the divided session.

Before examining the operation of the new arrangement it might be useful to summarize briefly the essential features of the theory of the sphit session. In the first place, it may be regarded as a means of improving legislative procedure and the conduct of legislative business as provision was made for the introduction of bills during the first portion of the

14 There is a brief critical analysis of the plan in the San Francisco Chronicle, Oct. 6, 1910. For a cautious and non-colnmital discussion, see San Francisco Call, Sept. 29, 1910. Certain Progressive-Republican leaders, notably Francis J. Heney, opposed it as unworkable.

15 The vote was 127,794 for, and 79,348 against, the amendinent.

16 Catre. Const. Art. IV., §§ 10, 15. 
session, their consideration during the recess, and their passage during the final weeks. Secondly, it may be regarded as furnishing desirable publicity, because the general public, as well as the legislators, would be given an opportunity to study the bills that had been introduced and readily to discover "bad" bills and "good" bills. Thirdly, the interval between sessions would also furnish to constituents an opportunity to make known to their representatives their opinions and wishes with reference to proposed legislation. Thus, desirable legislation could be more easily enacted and undesirable legislation defeated, according to the dictates of the people of the state acting as a sort of super-lobby. Finally, the restrictions upon the introduction of bills after the recess would effectively prevent the passage of hasty and ill considered measures during the closing days and hours of the session. The plan, considered in the abstract, lays claim to many virtues. ${ }^{17}$

\section{Operation IN 1913}

The plan was inaugurated under most favorable conditions. The legislature of 1913 was progressive in character, and its membership desired to act in full accord with the letter and spirit of the new arrangement. There was undertaken, therefore, an experiment probably never before attempted in the history of American legislative assemblies. By resolution, the secretary of the senate was directed to send, upon request, complete sets of introduced bills to county and city clerks, public hibraries, high schools, chambers of commerce, and boards of trade. ${ }^{18}$ In addition, each member was authorized to send complete sets to not more than ten constituents. This meant the state-wide distribution of proposed legislation.

The mechanical difficulties involved in the operation of this plan were truly appalling. At the close of the first part of the session, there had been introduced 3887 bills and constitutional amendments. There were 120 members of the legislature, which necessitated provision for 1200 sets. Each set contained 3887 separate parts, and the total number thus required for mailing constituted $4,664,400$. In addition, there were groups and individuals throughout the state that desired to study certam bills. That portion of the press which endorsed the plan endeavored to assist by publishing elaborate summaries of the various important measures, with results that were only partially successful. Citizens' meetings, sponsored by progressive orgamizations, considered pending legislation, were addressed by their representatives, and by resolution transmitted their views to legislators. In several rural districts members

17 There is an able statement of the purposes of the split session in West, California-The Home of the Split Session (1923) 12 NaT. Mun. Rev. 372-73.

18 SENATE JOURNAI, 40th session (1913) 472. 
called together their constituents, who, although interested, had few suggestions to offer. In short, the sincere attempts of many individuals and organizations intelligently to study the proposals and to make known their opinions, were circumvented by the magnitude of the task imposed upon them. There was manifestly a lack of tinie during the recess of thirty-three days for even a superficial analysis of the significant legislation, as well as a lack of knowledge on the part of the general public and no practical nethod of giving it the necessary information. ${ }^{19}$

Many of what are designated as pressure groups encountered no such difficulty, and their intelligent activity stood in suggestive contrast to the well meaning, but relatively ineffectual, work of the more or less unorganized voters. The legislative counsel and other experts connected with these organizations examined with meticulous care all introduced bills which in any degree affected their interests. Pamphlets were published which endeavored to show why this or that measure should or should not pass. The various chambers of commerce throughout the state were active; and their opinions concerning the advisability of proposed legislation were strikingly and suspiciously similar. ${ }^{20}$ The recess period also furmished an ample opportunity for the representatives of organized interests, public utilities and the like, to interview at length members of the legislature. When the second session convened, numerous lobbyists appeared on the scene "to explain" and "to educate." They have been characterized by a conipetent observer as "the most numerous, the nost powerful, and the most remarkable lobby that ever assembled at Sacramento."221 The varied interests which they represented were thus able to make themselves legislatively articulate and effective.

Despite some obvious disadvantages, the experience of California with the split session in 1913 hastened the transition in this state from the "old" lobby to the "new" lobby. It seems reasonable to believe that the practices under the divided session plan were a contributing factor in the final disappearance of the methods and tactics formerly so effective and far reaching in influencing legislation. Bribery and other sinister forms of influence were, of course, abandoned, but from the point of view of organization and effective dissemination of information, the old lobby paled into insignificance. Since 1913 the newer methods have, in the main, been followed both in California and elsewhere. The various nonpolitical associations, as they are today characterized, soon found it possible to function efficiently under the changed conditions. The newer

19 In the treatment of the recess period of 1913, the work of Franklin Hichborn has been ruthlessly pillaged. See HictBorN, STORy OF THE CAIIFORNIA LEGISLATURE of 1913 (1913) 106-111. Mr. Hichborn has generously placed at my disposal additional information concerning the activity between sessions in 1913.

20 Ibid. 112-113.

21 Ibid. 113. 
and more expensive, perhaps more insidious, propaganda was substituted for the older and cruder methods.

Since the 1913 session no attempt has been made to continue the plan of that year. During the past sixteen years, however, the split session has developed features which it might be useful to analyze. Included among these are, first, the duration and work of the first part of the session, including the skeleton bill practice; second, the activities during the recess of legislators and of organized groups; third, the introduction of bills in the second half of the session, and the character of legislative procedure and output; fourth, tentative conclusions concerning the operation of the split session plan.

\section{Legistative Activity During the First Part of the Session}

When the provision had been under discussion at the 1911 session, the understanding was that no bills would be acted upon during the prerecess session. This restriction was not definitely written into the amendnient, however, and the legislature has the power, prior to the recess, to consider any or all bills that may be introduced. In practice, the legislature has very rarely considered or enacted much legislation during the pre-recess period. During the last five sessions, 1921-1929, a total of 5254 bills were enacted of which only 42 were passed during the first part of the various sessions. ${ }^{22}$ Of these, 17 were deficiency appropriation nieasures, 6 were emergency appropriation bills, while the remainder concerned such matters as the validation of bond issues, amendments to the county government code, and payment of salaries and mileage of menibers of the legislature. ${ }^{23}$ Both in number and in content the bills passed in the period before the recess are comparatively insignificant. The initial portion has thus been utilized chiefly for organization, for the appointnent of committees, and for the introduction of bills. Legislative committees do not function actively until after the recess. These practices are in conformity with the intentions of those who originally endorsed the plan.

Fron 1913 to 1927 it was the custom of the legislature to remain in session between three and four weeks before recessing. ${ }^{24}$ In 1927 and in

22 In the following analysis the first figures following the date indicate the total number of bills enacted, the second, the number passed in the first portion of the session: 1921, 1152, 7; 1923, 890, 6; 1925, 999, 8; 1927, 1107, 12; 1929, 1106, 9.

23 The constitution provides that until the budget bill is enacted neither house shall pass any other appropriation measure, except emergency bills recommended by the governor, or appropriations for the salary and expenses of the senate and assembly.

24 The duration of the first part is as follows: 1913, Jan. 6-Feb. 4; 1915, Jan. 4-Jan. 30; 1917, Jan. 8-Jan. 26; 1919, Jan. 6-Jan. 24; 1921, Jan. 3-Jan. 24; 1923, Jan. 8-Feb. 2; 1925, Jan. 5-Jan. 24. See Final Calendars of Legislative Business (1913-1925) passim. 
1929 this practice was altered. The first portion of the 1927 session occupied less than three weeks, and in 1929 was reduced to ten legislative days. ${ }^{25}$ This change was strongly endorsed by the then governor, C. C. Young, and by other competent observers, who believed that the first part of the session could and should be materially reduced. ${ }^{26}$ The time thus saved could be well spent later in the consideration of legislation.

From the point of view of legislative methods, the preparation and printing of bills before the legislature assembles have been decidedly beneficial. During the autumn preceding each regular session a large number of legislative proposals have been prepared at the request of members of the legislature and of officials of the various state departments. Since 1914 this work has been done by the staff of the Legislative Counsel Bureau which has assisted with intelligence and with skill in the writing of bills. At the special session in 1928, each house, by resolution, provided for printing in advance of the session such measures as a member should certify it was his intention to introduce. ${ }^{2 \pi}$ It seems evident that this practice resulted in more orderly preparation of legislative business and did not increase the number of bills that otherwise might have been introduced. The preprinting policy is now authorized by statute. ${ }^{28}$ Prior to the session of 1929,650 measures had been prepared and a very large proportion of them printed before January 1 of that year. ${ }^{29}$

The skeleton bill practice, which violates the theory of the bifurcated session and which destroys its possible effectiveness, seems to have developed about 1919-1921. Under this ingemious arrangement, so-called skeleton bills are introduced during the first part of the session. They contain a regular bill number and a title, which may be complete or incomplete, and the following statement:

"The people of the State of California do enact as follows:"

Some legislation of this type has also several sections of the bill incorporated with important portions left blank. These are known as

25 Ibid. (1927) 3 ; Ibid. (1929) 3.

26 In his first message to the legislature, January, 1927, the governor declared: "I think that legislators are substantially agreed, inasmuch as the double session plan probably will continue in California, that it would be very desirable to limit the first portion of the session to as short a period as possible, just long enough to organize, to get committees appointed, and to introduce the bills. Now that many of the bills are being prepared in advance, I can see no reaason why under normal conditions the opening session need consume more than two weeks of your time, giving the week thus saved, if necessary, to the over-crowded second portion." First Biennial Message, 12.

27 Senate Journar, 48th session (extra, 1928) 4; Assembly Journar, 48th session (extra, 1928) 21. For the protection of the author, however, the text of a measure is never unade public without his instructions or request.

28 Cal. Stats., 1929 , c. 67.

29 During the first part of the session of that year, 890 bills were introduced in the senate and 1196 in the assembly. It is, of course, necessary to note that many of these bills were merely amendments to existing statutes. 
partial skeleton bills. Recently, the changed bill practice has developed. Bills introduced prior to the recess which seemingly pertain to one subject have been changed to another subject by amendment after the recess. The bill retains its number as originally introduced but the first title is stricken out and a new one inserted. In the same manner the sections as first written are eliminated and new sections incorporated which pertain to the revised title. In other words, only the number of the bill and the author's name are retained, everything else in the original bill having been changed. By this convenient practice a bill relating to the office hours of county officials becomes transformed into one relating to horticultural commissioners.

During the second part of the session the skeleton and partial skeleton bills are filled out. ${ }^{30}$ It is obvious that this practice nullifies one of the basic ideas of the divided session. The evil reached alarming proportions in the sessions of 1923 and of 1925 when 303 and 304 such bills, respectively, were introduced. ${ }^{31}$ In his inaugural address, Governor Young, who had had long legislative experience and was thoroughly familiar with the situation, criticized the practice and indirectly stated that such bills, if passed by the legislature, would be very critically examined by him. ${ }^{32}$ Indeed, the inpression was general that the great majority of skeleton bills faced certain veto. The resnlt was a sharp decrease in this type of proposed legislation both in the 1927 and in the 1929 sessions of the legislature. In the forner there were only 54 in the assembly and 27 in the senate, a total of $81 ;^{33}$ in the latter a total in both houses of 55 , including 37 in the assembly and 18 in the senate.

In both sessions a considerable number of skeleton bills related to county government. These so-called county government bills concern the salaries of various county officials. As the authorities in certain counties do not inform the legislature of the desired changes in the salaries,

30 For recent examples, see Grant, The Bicameral, Pranctple iN the California Legislature, 146 (Mss. Copy).

31 Ibid. 147. In 1923 a total of 1938 bills were presented during the first part of the session and in 1925 a total of 1845 .

32 "I also trust that something may be done this year to make impossible the introduction of so-called 'skeleton bills.' The constitutional provisions creating a legislative recess contemplated that each bill, at least as far as the intent and best judgment of the author is concerned, should be in its final form from the moment it is first submitted. Otherwise a public study of bills during the month of recess would mean nothing, . . . . If, however, there are skeleton bills, or bills otherwise essentially modified by author's amendments, and which assume their really intended form after the recess, the provision of the constitution is virtually nullified. It is accordingly obvious that the legislation which will be most sure of approval by the public and by the governor's office, will be that which is carefully drafted before its introduction, and passed through the legislature before that final grand rush which renders careful consideration so impossible." Inaugural Address of Governor C. C. Young (1927) 16-17.

33 GRANT, op. cit. supra note $30,147$. 
the senator or assemblyman from those districts proceeds on the assumption that the legislature, as a body, is not interested in proposals of this character affecting only particular counties. The recommendations of the county grand jury are also a factor in the consideration of salary changes; they usually are not available during the first part of the session. These circumstances make skeleton bills a virtual necessity in so far as they relate to county salaries.

The legislature has never shown any particular hostility toward the introduction of skeleton bills and has never taken a definite stand against the practice by refusing to receive such proposals, although occasionally a few members have personally protested. In the absence of gubernatorial objection and possible veto, the practice could easily be revived and even more fully developed. ${ }^{34}$

With reference to these practices, it seems doubtful whether a strict construction of the two-bill limit fixed in the constitution after the legislative recess would permit either the filling in of skeleton bills or the introduction in changed bills of amendments which virtually constitute new legislation. The transformation of skeleton and changed bills into new and additional measures during the final weeks and days of the session might result in a situation where practically no legislation would be introduced in its final form before the recess. No judicial determination of the question has yet been made.

\section{Activities AND INTERests DURTng the Recess}

By constitutional mandate a recess of both houses "must be taken for not less than thirty days." This period constitutes, in theory, one of the most significant features of the divided session plan because it gives the people opportunity to examine the proposed legislation, to discover both the "good" and the "bad". bills, and to consult their legislators concerning them. In point of fact, no such hopelessly impractical results have been obtained. The problems before the legislature, as reflected in the bills, are extremely various and complex. Among the electorate in California there is considerable diversity of economic and social interests with a resulting heterogeneity of political opinion. Individual determinable views on the numerous pending legislative proposals are simply nonexistent. It is likewise impossible for the representative to have much knowledge of the opinions of his constituents partly because, with reference to many questions, they have no opinions, and partly because there is not sufficient opportunity during the recess for either the representative or the constituency to examine even a small portion of the great num-

34 The first part of the 1931 session witnessed a startling revival of the practice. Over 500 skeleton bills, a larger number than ever before, were introduced, many of them during the final two days of the period: 
ber of bills. ${ }^{35}$ Indeed, since 1913 , members of the legislature have very rarely attempted to ascertain what may be termed district opimion in matters of theoretical common interest.

It should not be assumed, however, that there is no activity in the respective districts or among the legislators during the recess. The various organized non-political groups are often exceedingly active during the thirty day interval, which furmishes them an opportumity to examine with care legislation in which they are interested. During a recent recess, comprehensive digests of all bills directly or indirectly affecting certain orgamizations were prepared. The proposals embodied in legislation concerning real estate, agriculture, private corporations, banking, labor, education, building and loan associations, old-age pensions, municipal and county affairs and other pending issues are thus made known to the members of the particular group within the body politic. ${ }^{36}$ In the interest of legislative protection or of legislative privilege, non-political forces can be easily mobilized and great pressure brought to bear upon legislators who, in many instances, are sensitive to the dictates of those organized elements which have a definite progran and know what they want. The expressions of the vigilant groups may or may not refiect the socalled opinion of the constituency, but they frequently are none the less effective. There is manifestly nothing improper in this practice, which results in considerable publicity, both in the press and elsewhere, concerning proposed legislation. Only rarely, however, can it be imterpreted as public opinion held by the people of the particular district.

Opportunity is likewise afforded during the recess for administrative officers, state and local, to study proposed measures. In many districts it is customary for senators and assemblymen to hold conferences during the recess with the representatives of the various orgamizations and to ascertain their opinions concerning proposed legislation. Legislators continually receive from the spokesmen of groups which respectively advocate and oppose the adoption of pending legislation suggestions and requests concerning a considerable number of bills. ${ }^{37}$ Many communications are received daily by individual members; these are usually inspired

35 It will be recalled tbat the original Caminetti proposal adopted by the senate had fixed at ninety days the minimum interval between the first and second sessions.

36 For example, the building and loan associations prepared in 1929 a very coinprehensive digest covering bills which concerned their interests, including taxation, mechanics' liens, and recording of deeds. Certain labor interests and building material groups advocated a bill which gave preferment to a mechanics' lien; this was strongly opposed by the building and loan element.

37 During a recent recess, a member of the senate, in a period of three days, conferred with nime groups in his district. They represented, among others, the interests of agriculture, education, private corporations, labor, and real estate. 
and show a striking similarity of content. ${ }^{38}$ Each day the mail, the telephone, and the telegraph bring inquiries or advice, occasionally from individuals as such, but chiefly from one or more of the very numerous nonpartisan associations. Inquisitive and well meaning civic groups, luncheon clubs, and patriotic societies invite members of the legislature to present to them, in thirty minutes, an analysis of the most important pending legislation, requests obviously impossible to fulfill.

The artificial grouping of people into standardized districts for the purposes of representation thus remains, but the conflicts of ideas and of opinions concerning legislation are often state-wide and do not recognize the arbitrary and frequently illogically formed legislative areas. In this manner and by these somewhat heroic methods the ancient plan of representation by district is modified in an extra-legal and relatively effective fashion.

Apparently no settled policy has been developed by the press as a whole concerning the explanation and the analysis of proposed legislation. From the beginning, the split session has been caustically criticized and ridiculed by certain newspapers and warmly defended and supported by others. Practically all of them, however, give considerable publicity during the recess to ineasures which have been introduced. Some journals prepare and publish systematic summaries of the various bills according to topics, and nearly every day several columns are devoted to an explanation of their chief features.

In 1929, the San Jose Mercury published a series of twenty-one articles. Seventeen of these were digests of pending measures, a useful method of publicity which has been followed successfully by other newspapers. ${ }^{39}$ Editorials which criticize or endorse legislation frequently appear. In other instances, attention is directed only to those introduced bills which seem of particular significance to the community or which have aroused local interest. During the session of 1927 an important metropolitan paper published during the recess period of thirty days twenty-one articles and two editorials commenting upon certain bills, while, two years later, seventeen articles and four editorials appeared. ${ }^{40}$ Some of the articles analyze, in part, bills covering several subjects. It

38 Some two hundred identical letters concerning a certain bill were received within two days by a member of the legislature, and frequently there are clear indications that the communications emanate from the same source.

${ }^{39}$ See the issues from January 3 to February 14, 1929. The Sacramento Bee has pursued with effect a similar policy.

${ }^{40}$ San Francisco Chronicle, January 23 to February 22, 1927; January 18 to February 17, 1929. An examination of the files of the same journal during the recess of 1915 and of 1923 indicated a similar amount of publicity. Another opponent of the bifurcated session, the Ios Angeles Times, follows the same practice. In 1917, for example, nine articless and eight editorials were published between the first and second sessions. 
seems probable that the press will continue during the recess to make available, in one form or another, much information concerning legislative activity and proposals.

One mechanical defect has occasionally prevented even a partial realization of the benefits of the divided session. Many bills are hastily prepared and hundreds are introduced on the last days of the first portion of the session.11 The facilities for printing and distributing the bills have been inadequate, and nearly three weeks of the recess period have elapsed before the material reached the legislators and other interested individuals and groups..$^{42}$ This difficulty could be met by a longer recess, which seems impractical; by improved methods of distribution; and by the pre-session preparation and printing of bills. A combination of the latter two is the inost feasible plan, and, as has been shown, a commendable effort is being made by the Legislative Counsel Bureau to achieve that result. There is also prepared in the office of the counsel a Legislative Digest which is decidedly useful in stating concisely the salient features of each bill. Critical comments and suggestions are not incorporated save for the confidential use of the member introducing the bill. It is obvious that the digest should be available alike to legislators and to others during the entire recess interval.

As the members return to their respective homes it is not possible to hold meetings of the standing committees, althougl informal conferences of the leaders may be, and are, called to consider important matters which are to come before the legislature. The committee chairmen likewise have an opportunity further to study and to classify the bills whicl are under their jurisdiction.

Special and investigating committees, however, constitute somewhat of an exception to the general practice. As agencies of criticism of the conduct of the executive or in securing information upon which subsequent legislation may be based, the recess period affords an opportunity for more extended examination than would otherwise be possible. In the main, the investigations have concerned matters which seemed to demand legislation rather than inquiries into the conduct of the administrative

41 The exact figures indicating, respectively, the number of bills introduced in each house during the last five days of the first part of the session and the total number introduced in that period are: 1915, Senate 685, 1202, Assembly, 866, 1484; 1917, Senate, 802, 1131, Assembly 888, 1342; 1919, Senate, 556, 698, Assembly, 771, 994; 1921, Senate, 770, 923, Assembly, 985, 1203 ; 1923, Senate, 452, 680, Assembly, 782, 1258; 1925, Senate, 592, 773, Assembly, 901, 1192; 1927, Senate, 553, 827, Assembly, 777, 1147; 1929, Senate, 560, 816, Assembly, 721, 1045. These figures have been secured from the Final Calendars of Legislative Business, 41st to 48th Sessions, (1915-1929) passim.

42 A similar difficulty was encountered in West Virginia during the years 192129. See Faust, Results of the Split-Session System of the West Virginia Legislature, (1928) 22 Aar. Poz. Scr. Rev. 109, 118. 
branch. ${ }^{43}$ The proceedings and conclusions of these committees have served to bring before the public important information concerning the necessity for legislative action. Some decidedly effective work has been accomplished, but whether this use of the recess period justifies the divided session seems highly doubtful.

\section{The Second Part of the Session}

Constitutional provisions restrict materially the introduction of bills upon the reassembling of the legislature. To introduce a bill in either house consent of three-fourths of its membership is necessary, while no member may present more than two bills. These restrictions were intended, of course, to prevent a flood of new bills from descending upon the legislature near the close of the session and to concentrate time and attention upon the legislation already presented. ${ }^{44}$ The legislature has been very considerate in permitting each member his full constitutional privilege. It is practically unknown for objections to be raised, despite the subject matter of the bill. Even in the highly controversial matter of prohibition there is apparently no attempt to prevent the introduction of legislation after the recess. During the period under discussion, 19151929 , the average number of bills introduced in the senate with a menbership of 40, was 67 ; in the assembly, with a membership of 80 it was 130.15

An examination of the content of bills introduced during the second part of several sessions reveals that no particular type predominates. An infinite variety of subjects is included. The proposals are, for the most part, general in scope; with the exception of private claims, very few are local bills. The subject matter is invariably similar to that of bills introduced before the recess. Apparently it is not the practice of members to hold back important legislation in the hope that it will be placed on the

43 For example, inquiries bave been instituted concerning expenditures of money in election cainpaigns (1923); the so-called "Cement Trust" (1929); workmen's coinpensation rates, especially in the mining industry (1931). Since 1923, the number of investigations, both during and between legislative sessions, has increased.

44 There is no limit on the number of constitutional amendinents, and joint or concurrent resolutions which may be introduced after the recess.

\begin{tabular}{cccccccc}
\multicolumn{3}{c}{ 45 } & Senate Bills Introduced: & \multicolumn{4}{c}{ Assembly Bills Introduced: } \\
1915 & 1st Part & 2nd Part & Total & \multicolumn{3}{c}{ 1st Part 2nd Part } & Total \\
1917 & 1202 & 67 & 1269 & 1915 & 1484 & 124 & 1608 \\
1919 & 1131 & 72 & 1203 & 1917 & 1342 & 131 & 1473 \\
1921 & 698 & 63 & 761 & 1919 & 994 & 124 & 1118 \\
1923 & 923 & 63 & 986 & 1921 & 1263 & 100 & 1363 \\
1925 & 680 & 70 & 750 & 1923 & 1258 & 120 & 1378 \\
1927 & 773 & 60 & 833 & 1925 & 1172 & 146 & 1318 \\
1929 & 827 & 70 & 897 & 1927 & 1147 & 147 & 1294 \\
1929 & 74 & 890 & 1929 & 1045 & 151 & 1196
\end{tabular}

These figures have been compiled from the Final Calendars of Legislative Business, 41st to 48th Sessions (1915-1929) passim. 
statute books after perfunctory consideration. ${ }^{46}$ With few exceptions there are no differences of significance in the number of bills introduced under the single session and the divided session plans. ${ }^{47}$

There is no constitutional restriction concerning the duration of the second part of the session. Members receive a fixed sum of twelve hundred dollars per year, together with certain limited allowances for mileage and for contingent expenses. ${ }^{48}$ Since the introduction of the divided plan, it has been customary for the legislature to remain in session approximately two months after it reconvenes. In 1921 the second period occupied less than sixty days, while in 1929 it was about ninety days. ${ }^{40}$ The total length of the sessions, including the thirty day recess, is therefore somewhat less than four months, a period of time considerably longer than is ordinarily found in other states.50 Many members of the California legislature consider the lengthy session one of the most undesirable features of the entire plan.

Despite the innovational character of the split session it can hardly be said that it has resulted in any considerable improvement in the actual legislative process or in the quahity of the legislative output. The chaotic haste incident to the closing days of the session has continued; indeed, there are those who believe the hurry and confusion have increased in recent years. The great expansion of state activity in fields heretofore unoccupied has made it necessary to consider and to enact much legislation dealing with a great variety and complexity of subjects. There is at every session a bewildering profusion of bills, which, with a bicameral form of legislative organization, and with a complex committee system, combine to produce disorganization and decentralization.

It is simply a fact that considerably more than half of the legislation is passed during the last ten days of the session. The final enactment of hundreds of bills, nuany of which the inembers have not had an opportunity to read, much less to analyze, is crowded into a brief legislative period. An examination of four sessions, 1923-1929, indicates that a total

. 48 It is not necessary here to catalog the bills. Typical examples include various amendments to the codes; public works; irrigation districts; public health; highways. 47 Total number of bills introduced:

Year............1905 $1907 \quad 19091911191319151917 \quad 191919211923192519271929$

$\begin{array}{llllllllllllll}\text { Senate ........ } 888 & 949 & 1254 & 1890 & 1783 & 1269 & 1203 & 761 & 923 & 750 & 833 & 897 & 890\end{array}$

Assembly....1180 $10391451158821391608 \quad 1473 \quad 111813631378 \quad 131812941196$

Final Calendar of Legislative Business, 48th session (1929), Senate, 14; Assembly, 89. 48 Calir. Const. Art. IV, \$23.

40 Final Calendars of Legislative Business, 41st to 48th Sessions, passim. In West Virginia, however, the final session could not continue longer than forty-five days, except with the concurrence of two-thirds of the total membership. W. VA. Const. (1921) Art. VI, \$22.

50 About two-thirds of the state constitutions specifically limit the legislative term; many are 60 or 90 days. 
of 4144 bills were passed by both houses; of these, some 2495 , or 60.2 per cent, including appropriation bills, were hurried to the statute books in the final ten days. ${ }^{51}$ Under these circumstances, it becomes manifestly impossible for members to know very nuch concerning many of the bills which are enacted during the end of the session rush. It would probably be correct to say that only in those instances where the legislator has special knowledge or interest is he informed as to the content and significance of the legislation which is rapidly passed before his very eyes.

\section{CONCLUSION}

The experience of California seems adequately to demonstrate the wide variance between the theory and the practice of the bifurcated session. Although designed to correct, at least in part, some of the worst features of the legislative practices that prevailed, the operation of the plan has obviously not accomplished that result. It is often difficult to detect in the record of the practice any of the ideas that formed the theory.

Is the great difference between the theory of the divided session and the facts of its operation attributable to error in the theory or to error in the practice? Probably both, but certainly in the theory. The assumption that the public is, or can be, interested in the numerous and shifting proposals which come before successive legislatures is not in accord with the firm realities of politics and government. Many persons sinply do not desire to participate; as has been convincingly said, they do not come "near to embodying the accepted idea of the sovereign and omnicompetent citizen." in the desires of the electorate are factors which sharply reduce even the possibility of widespread popular interest in the issues before the legislature. There are seldom any manifestations of that popular will which is sometimes alleged continuously to direct public affairs and to translate

\begin{tabular}{|c|c|c|c|c|c|}
\hline \multicolumn{6}{|l|}{51} \\
\hline Year & \multicolumn{2}{|c|}{$\begin{array}{l}\text { Total Number } \\
\text { of bills passed }\end{array}$} & $\begin{array}{l}\text { Bills passed } \\
\text { last ten } \\
\text { days }\end{array}$ & $\begin{array}{c}\text { Percentage of } \\
\text { bills passed last } \\
\text { ten days }\end{array}$ & $\begin{array}{l}\text { Percentage of bills } \\
\text { passed last ten } \\
\text { days carrying } \\
\text { appropriation }\end{array}$ \\
\hline \multirow[t]{2}{*}{$1923 \ldots . . . .}$. & Senate & 333 & 210 & 63.1 & 17.1 \\
\hline & Assembly & 599 & 277 & 46.2 & 20.9 \\
\hline \multirow[t]{2}{*}{$1925 \ldots . . . .}$. & Senate & 365 & 242 & 66.3 & 19.8 \\
\hline & Assembly & 634 & 433 & 68.3 & 22.9 \\
\hline \multirow[t]{2}{*}{$1927 \ldots \ldots$} & Senate & 455 & 321 & 70.6 & 12.5 \\
\hline & Assembly & 652 & 351 & 53.9 & 31.9 \\
\hline \multirow[t]{2}{*}{$1929 \ldots$} & Senate & 454 & 201 & 44.3 & 15.9 \\
\hline & Assembly & 652 & 460 & 70.6 & 24.0 \\
\hline
\end{tabular}


public policy into law. ${ }^{53}$ The activity of special interest groups has developed under the split session, while the press lias contributed useful, if spasmodic, publicity. These factors are often helpful but whether they are an intelligent expression of opinion or result in effective popular control over legislative pohicies seems quite uncertain. Nor does it seem possible, in view of the complex questions which in the elaborately organized technological civilization of today demand governmental action, that the somewhat heroic device of the divided session will ever be more than partially effective.

So far as legislative procedure and consideration are concerned, no very significant changes have occurred since 1913 . The confused incompetence of the American legislature and the distressing manifestations of legislative indifference and irresponsibility remain. It seems futile to hope that the divided session alone can be a really effective remedy for the more deep-seated legislative ills. Probably a majority of the members of the California legislature, with the longest legislative experience, are critical of the divided session and idesire its abolition. ${ }^{54}$ It does not seem possible, however, to secure the majorities necessary to submit an amendment abolishing or seriously modifying the present arrangement. ${ }^{55} \mathrm{De}-$ spite its obvious defects, therefore, it is safe to predict that the California legislature will continue in the future, as for some time in the past, more or less satisfactorily, to function under the divided session.

Thomas S. Barclay.

STANFORD UNIVERSITY

53 It is believed by some careful observers, however, that on one occasion the divided session served a very useful purpose and afforded an opportunity for securing statewide discussion of an important revision in the tax law. This situation arose in 1921 in connection with the so-called King Tax Bill. The proponents of this measure, which had been defeated in the assembly during tbe first part of the session, utilized the recess period to organize public opmion for its passage. As a result, a second bill was introduced, and, after a long and bitter controversy, was finally adopted. This instance has been defended as a justification for the split session and as a vindication of the claims of Senator Caminetti, but, at best, such occurrences will be only occasional. For a detailed treatment of this legislation see HicHBorN, Story of tHe CaLIForRIa Legislature of 1921 (1921) chaps. III-VIII.

54 Since 1913 no less than forty-sever proposals altering or abolishing the divided session have been introduced in the legislature. Of recent years, bowever, they bave become less frequent.

55 The California Constitutional Counmission, in its report containing a revision of the state's fundamental law, has made no provision for the split session. It was believed that the question involved a matter of procedure which should be left to the legislature. Report of the CacIfornal Constitumionat Commission (1930) 11. 